\title{
Pre-Service English Teachers' Voices About the Teaching Practicum
}

\section{Las voces de los profesores de inglés en formación acerca de la práctica pedagógica*}

\author{
Jairo Enrique Castañeda-Trujillo \\ jecastaneda@unisalle.edu.co
Ana Jackelin Aguirre-Hernández anajaguirre@unisalle.edu.co Universidad de La Salle, Bogotá, Colombia

This paper shows the results of a pedagogical experience with a group of pre-service English teachers during their first semester of teaching practicum. The data were collected by means of reflection papers written by them, and then the resulting papers were analyzed under the principles of codification of grounded theory. The results show that pre-service English teachers develop a sense of awareness of the context they work on. Also, the mentor teacher is important in such understanding, because she or he provides theories and personal experiences that contribute to the reflection. Finally, we conclude that pre-service teachers' reflections could contribute to curriculum development, so, it is advisable that language teacher education programs provide the mechanisms to give them a voice.

Key words: English language teacher education, pre-service English language teachers, reflection, teaching practicum.

Este artículo muestra los resultados de una experiencia pedagógica con un grupo de docentes de inglés durante su primer semestre de práctica docente. Los datos fueron recolectados por medio de

* $\quad$ Received: October 1, 2017. Accepted: November 23, 2017.

How to cite this article (APA 6th ed.):

Castañeda-Trujillo, J. E., \& Aguirre-Hernández, A. J. (2018). Pre-service English teachers' voices about the teaching practicum. HOW, 25(1), 156-173. https://doi.org/10.19183/how.25.1.420.

This article is licensed under a Creative Commons Attribution-NonCommercial-NoDerivatives 4.0 International License. License Deed can be consulted at https://creativecommons.org/licenses/by-nc-nd/4.0/. 
reflexiones escritas por ellos y luego analizados bajo los principios de codificación de la teoría fundamentada. Los resultados muestran que los futuros profesores de inglés desarrollan conciencia del contexto en el que trabajan. Además, el maestro mentor es importante porque él o ella proporciona teorías y experiencias personales que contribuyen a la reflexión. Finalmente, concluimos que las reflexiones de los futuros profesores pueden contribuir al desarrollo del currículo, por lo que es aconsejable que los programas de educación de profesores de idiomas proporcionen los mecanismos para darles una voz.

Palabras clave: práctica pedagógica, profesores de inglés en formación, reflexión.

\section{Introduction}

The teaching practicum has been considered one of the most crucial and influential stages in teacher education (Trent, 2013). The teaching practicum allows pre-service teachers to become exposed to the real world of teaching English to students of other languages and to gain knowledge about the complexity of current classroom practices, which contribute to enhancing pre-service teachers' motivations, attitudes, and engagement towards the teaching profession (Fajardo \& Miranda, 2015). Nevertheless, for some, the teaching practicum could also become one of the most challenging, puzzling, tough, and unsatisfying experience along the BA program (Farrell, 2001; Ferrier-Kerr, 2009; Trent, 2013). Whatever the effects the teaching practicum could have on pre-service teachers, these can affect their learning experiences, confirming or changing the impressions they had about the teaching practicum before enrolling in the BA program (Calderhead, 1988).

With the idea of exploring more about pre-service teachers' teaching practicum, we decided to systematize a pedagogical experience that we had in a scenario of teaching practicum from three main aspects associated with pre-service teachers' most frequent concerns, namely: (a) understanding their own classroom, (b) learning from their mentor teacher, and (c) mastering the art of language teaching in general (Brinton \& Holten as cited in Farrell, 2001). This article shows how pre-service English language teachers perceive their classrooms during their field-based experiences (the teaching practicum), and in this way, we hope to unveil how aware they are of the need for a change in language teaching processes.

\section{Literature Review}

\section{Studies in Colombia}

Some scholars in Colombia have done research about certain aspects that are also related to the teaching practicum; these studies help us to deepen our understanding of what happens in this scenario within the national context and we want to acknowledge some of them. 
Camacho et al. (2012) and Cote (2012) analyzed pre-service teachers' reflection process along with their teaching practicum based on Schön's theory (reflection in action and reflection on action) and Van Manen's three levels of reflection (technical, practical, and critical). The main conclusions of these studies indicated that pre-service teachers are engaged in constant reflection and make decisions on the spot based on their own personal vision of what can favor the educational situation, but this reflection just reached the technical level in most of the cases.

Macías and Sánchez (2015) also undertook research with pre-service teachers in the teaching practicum. The study presents pre-service teachers' difficulties during their teaching experiences as well as the decisions they made in order to maintain the control and organization of the classrooms. The authors finally recommended strengthening the partnership between university and schools in preparing pre-service teachers; furthermore, they proposed some adjustment to the curriculum in order to have pre-service teachers know about school contexts at an earlier stage during their major.

Another study was directed to analyze pre-service teachers' narrative events written at the end of their teaching practicum (Castañeda-Peña, Rodríguez-Uribe, Salazar-Sierra, \& Chala-Bejarano, 2016). The article reported the experiences of 184 pre-service students and the main purpose was to identify and characterize different meaningful aspects that preservice teachers mentioned in their writings derived from their experiences in the teaching practicum. The main conclusions explain that pre-service teachers have a strong relationship with their pedagogical advisor in three main areas-pedagogical, social, and emotionalwhich are assumed to be sources of knowledge. However, there is no evidence about the promotion of reflection by advisors; pre-service teachers focused more on lesson planning and the development of tasks assigned by the teachers at the school where the practicum was taking place. Some recommendations given by the researchers had to do with the preparation of pedagogical advisors and the role they must play in pedagogical terms for pre-service teachers to improve in activities and methodologies.

Other studies that focused on pre-service teachers do not show a direct relation with the teaching practicum, but the aspects developed there could have significant repercussions on it. Some of the studies were oriented towards pre-service teachers' beliefs (I. Aguirre, 2014; Castellanos, 2013; Fajardo, 2013; Gutiérrez, 2015; Higuita \& Díaz, 2015), perceptions about ideological influence (A. Cárdenas \& Suárez, 2009; Viáfara, 2016), the development of their research skills (M. L. Cárdenas, Nieto, \& Martin, 2005; Posada \& Garzón, 2014), the improvement of linguistic or intercultural competencies (Castro \& López, 2014; Fajardo \& Miranda, 2015; Franco \& Galvis, 2013; Ramos, 2013; Viáfara, 2008), their reflections on language teaching (Castillo \& Díaz, 2012; Morales, 2016); also, some others propose changes for the curriculum for language teacher education programs in regard to the teaching practicum (J. Aguirre \& Ramos, 2011; Bonilla, 2012; Bonilla \& Méndez, 2008; Fandiño, 2013; 
Granados-Beltrán, 2016; Méndez \& Bonilla, 2016; Samacá, 2012). From this account, we can determine that there is a need to continue doing research with pre-service teachers but specifically in the teaching practicum, and exploring how this experience affects pre-service teachers' vision regarding language teaching and learning.

\section{The Teaching Practicum Within Teacher Education}

According to Freeman (2001), teacher education is "the sum of experiences and activities through which individuals learn to be language teachers” (p. 72). This learning can be taught, as in courses, or acquired by means of experience, which must guarantee that the pre-service teachers can develop all the skills required to become professional teachers.

However, some failures in the teaching education system can be identified in relation to providing pre-service teachers with the adequate procedural knowledge of classroom as well as their tackling other issues such as pupils, the limited time to build a realistic view of teaching, and ways to cope with the current difficulties that may arise in the different educational scenarios. Instead, teacher education has been limited to the transmission of established knowledge that most of the time is seen as immutable and, according to Bullough (1990) and Lucero (2016), focuses on content, disciplinary, and sociocultural knowledge; that is, teacher education appears to be centered on what mainstream authors consider every teacher should know about what and how to teach a language.

While teacher educators keep aligned to those imposed knowledge and practices, there is no space for a pre-service language teacher to explore different alternatives. Pre-service language teachers just have to respond to those requirements and continue replicating consumerism models that produce mass knowledge, without any kind of reflection about the context they want to intervene in (Martínez Boom, 2009). In this sense, Freire (1996), who was critical of this kind of education, made a wake-up call to all educators, in general, to provide learners the possibility of rewriting the world by being critical and by becoming able to read the different realities about educational settings.

Some courses related to human development, sociocultural awareness, education for peace, and so on, have been incorporated in the different teacher education programs in an attempt for including the social component. Furthermore, these courses are not oriented toward future educators only, but toward any professional, which could become a learning opportunity for future teachers. Nevertheless, these courses have not been designed for having pre-service teachers become aware of the educational realities they will face in their careers, and in this way, they turn into just another subject-matter to approve. Fajardo and Miranda (2015) argue that teacher education programs need to build up strategies towards preparing pre-service teachers for professional development and growth. 


\section{Context, Participants, and Description of the Experience in Teaching Practicum}

To collect pre-service language teachers' voices, we conducted a small-scale descriptive research with ten pre-service English language teachers who were in their first semester of the teaching practicum. We assumed the role of mentors of these pre-service English teachers, which let us interact with them and assigned some activities that led them to reflect upon their experiences in the teaching practicum.

These pre-service language teachers had taken some courses regarding methodology and didactics in which they received some instructions on how to prepare a language class and how to manage the classroom. However, university courses did not provide any type of contextualization on the school where they would be doing their practicum, their rules for lesson planning, the grading process, the routines of the classroom, or any other procedure school authorities demand from teachers, much less an adequate knowledge of pupils (Farrell, 2001; Kagan, 1992).

In this particular case, the scenario of the teaching practicum was a girls' state school in the south of Bogotá. The pre-service English language teachers had to go to the school one weekday to work with two different grades (from preschool to fifth grade) for about one hour and a half. ${ }^{1}$ Only two out of ten participants had some experience teaching English in language institutes and some of the others with preschoolers.

The program in which the participants were enrolled consisted of ten semesters. Three semesters (seventh, eighth, and ninth) are usually set aside for the teaching practicum. Once a week, the pre-service teachers met with us, their mentors, and analyzed some aspects related to the teaching practicum; after that, pre-service teachers were expected to write some reflections about their experiences in the classroom where they were teaching. Some of the aspects they covered had to do with the preparation for the class, the way students responded to the different activities, the feelings pre-service teachers had about their classes at the end of the day, and how they felt their mentor had helped them to overcome problems or to solve questions.

\section{Results of the Pedagogical Experience: Listening to Pre-Service Teachers' Voices}

Once we collected the reflections, we started to analyze them using content analysis from an interpretative approach (Berg \& Lune, 2012). Although our main intention was

In many state schools in Bogotá it is common to find that the English class in primary school usually lasts 1 or 2 hours a week, and in most of the cases, the teacher in charge of this subject has a low command of the foreign language because it is not his/her area of expertise. So, in many schools in which pre-service teachers go for their teaching practicum, they become the only "real" English teacher pupils have. 
not to generate theory about what happened with the pre-service teachers during the teaching practicum, we based the analysis of data on the principles of grounded theory, which, according to Richards (2003), "offers a means of developing an understanding of educational contexts" (p. 16), and the main principles of coding (Barbour, 2014) to establish common patterns of three main a priori categories: Pre-service English language teachers' understanding of their own classroom, Pre-service English language teachers' learning from their mentor teacher, and Pre-service English language teachers' language teaching. Figure 1 summarizes the results of the analysis.

\begin{tabular}{|c|c|c|}
\hline \multicolumn{3}{|c|}{ Pre-service English language teachers' understanding of their own classroom } \\
\hline $\begin{array}{l}\text { Awareness about the need } \\
\quad \text { for reflection time }\end{array}$ & $\begin{array}{l}\text { Social and human } \\
\text { individuality }\end{array}$ & $\begin{array}{l}\text { To become facilitator } \\
\text { and model }\end{array}$ \\
\hline \multicolumn{3}{|c|}{ Pre-service English language teachers' learnings from their mentor teacher } \\
\hline \multicolumn{2}{|c|}{$\begin{array}{l}\text { Appraising mentors' } \\
\text { guidance }\end{array}$} & $\begin{array}{l}\text { s from other teachers' } \\
\text { experiences }\end{array}$ \\
\hline \multicolumn{3}{|c|}{ Pre-service English language teachers' language teaching } \\
\hline \multicolumn{2}{|c|}{$\begin{array}{l}\text { Objectification and normalization of ELT } \\
\text { through the reflection process }\end{array}$} & $\begin{array}{l}\text { ig as an opportunity } \\
\text { for learning }\end{array}$ \\
\hline
\end{tabular}

Figure 1. Results From the Analysis of Pre-Service Teachers' Reflections

\section{Pre-Service English Language Teachers' Understanding of Their Own Classroom}

This category focuses on the different knowledges pre-service teachers construct from their own experience and their perceptions about the classroom they were assigned during the teaching practicum. In this sense, we determined three main issues: awareness about pupils' individuality, social and buman individuality, and the teacher as facilitator and model.

Awareness about the need for reflection time. Most of the time, pre-service teachers are ready to face the classroom based on all the instruction that they have received during their classes at the university. However, along these classes there is no time for reflection about what they expect to find in their classrooms. This could make them feel concern about whether or not the knowledge they have acquired and the abilities they have are enough to deal with classroom issues. Woods and Kwo (as cited in Orland-Barack \& Yinon, 
2007), maintain that "the structure of the preparation program often provides little time for reflection and for engaging in reflective tasks" (p. 958).

According to our data, during their teaching practicum, pre-service teachers are constantly thinking about their classes, the role they play in the classroom, the ideal class they should have, and the impact they are causing not just in terms of language but the way they can change their pupils' lives. Nevertheless, something they have in common is that there are not enough spaces (times and places) where they can share their experiences, beliefs, fears, and so on. In fact, such spaces are very relevant and actually the "core" reflection that examines how core qualities such as empathy, compassion, flexibility, creativity, and sensitivity operate to assist teachers in making sense of how implicit personal theories play out in explicit practice (Korthagen \& Vasalos, 2005).

Then, the need of having more subject-matters in the curriculum and the academic program to share what pre-service teachers think, find, and face become stronger when their voices are heard. Laura, one of the pre-service teachers, argues:

We shared what we have passed in our classrooms with the teacher and our partners, but one hour for all of us is not enough and we concentrated more on the lesson plan and the tasks we have to do in the school. ${ }^{2}$

In this case, Laura goes beyond the classroom and reflects on her effort to improve as a teacher and the outcome she can get to do so. Likewise, as in Lucia's case, pre-service teachers are concerned about their pupils' lives and how through their practicum they are able to change the pupils' realities. However, not enough time or spaces to share thoughts and experiences is an important aspect that can be observed all along the practicum. Hence, this kind of reflection is just shared on the paper.

Lucero (2016) argues that the pedagogical practicum is an event that brings to life the feelings, beliefs, and background experiences of both mentor teachers and pre-service teachers about teaching a language and the fact of being a teacher. Bearing in mind what Lucero proposes, one can see that listening to pre-service teachers' voices enriches their own practicum, allows them to be aware of their own process as well as to build up some strategies to better their experiences with their pupils, their partners, and their mentors.

Despite most pre-service teachers being focused on their classroom realities, the main concerns they hold have been linked to two different aspects related to the individuality of their pupils: the social and human individuality and the teacher as facilitator and model.

Social and human individuality. Being part of the society implies a different role depending on the place we are in and the tasks we have to achieve (it does not matter about

Excerpts have been transcribed verbatim. 
the age or genre) and that is why school success does not involve only academics. Patrick and Ryan (2005) state that

Schools and classrooms are inherently social places, and students go about their work in the presence of many peers. To understand students' success at the school, therefore, we must attend to their relationships with others at the school and the ways in which environment promotes different types of social interactions and relationships. (p. 271).

Consequently, family environment, pupils' context, and personal interest also influence social interaction at school.

In general terms, pupils arrive at the classroom dealing with their personal issues which influence their behavior, learning process, motivation, and responses. Lucia thinks about her students' context and how, through her classes, she can help them to overcome their personal problems:

Therefore, my first real experience as a teacher made me realize that being a teacher is educate good humans for this society...I understand that I have to be concerned and understand the problems that my students had at home and try to do their lives a little better during my class.

In the same way, Alicia focuses on listening to her students to be able to learn from them:

I learned that I have to take into account the context of the girls, how they learned, what they like, how they feel comfortable and the most important thing is to listen to my students.

And Luz highlights the relevance of a pupil's individuality:

Therefore, no child should be forced to learn since; each one is completely different and able to develop much learning.

On an individual-focused level, Patrick and Ryan (2005) argued that "the way students perceive various aspects of the classroom social environment relates to their own beliefs, which are associated with the use of strategies that in turn influence the nature and extent of their engagement and achievement in academic tasks" (p. 283). Then, the role of the preservice teachers as facilitators and models to help their pupils to transform their own reality takes place (Patrick \& Ryan, 2005).

To become facilitator and model. For pre-service teachers, becoming a teacher involves analyzing their own classroom, the activities they design, and the way they teach their classes to make them significant. As Peters (2012) claims, "pre-service teachers need to develop the skills and attitudes that enable them to critically reflect on others' and their own practice" (p. 35). Next, we can see what Alicia and Juliana think of their personal experiences: 
I need to understand my students and analyze them. In some classes, I was forced to look for different strategies to teach, because I realized that everybody learns differently. (Alicia)

Juliana finds her experience satisfying and looks for ways to improve her students' skills and likes:

One positive aspect in my pedagogical practicum has been the interest of my students. They are very clever despite some of them are undisciplined. They can participate actively, so I try to create a good environment for them to explore their talents, some are good artist others are good doing activities in group.

When mentors highlight the relevance of sharing experiences, pre-service teachers become aware of the role they have in their partners' leaning-teaching process.

\section{Pre-Service English Language Teachers' Learning From Their Mentor Teacher}

This is the second aspect proposed by Brinton and Holten (as cited in Farrell, 2001). Here, the role of the mentor teacher becomes important since pre-service teachers may need many structured opportunities to talk to mentor teachers about the reasons they have to make the decisions they make, how they solve pupils' problems, how to design a curriculum, and so on. Sahan (2017) affirms that "the most important factor in training qualified teachers is how qualified the instructors training them are because teachers can generally be as much qualified as their trainers" (p. 224), which suggests that pre-service teachers need to be supported to develop the skills needed to be a teacher. In this way, two subcategories emerged from the data: appraising mentors' guidance and learnings from other teachers' experiences.

Appraising mentors' guidance. Sahan (2017) says that "the important role teachers have in educational systems require mentor teachers to be equipped with certain knowledge and skills" (p. 217). For instance, the participants of this study hope to have mentors who have specific skills based on their experience and who correspond to the image of the ideal teachers they would like to be.

Laura highlights the results she can get from having a qualified mentor:

It's good to have a prepared teacher to help you, I think that it marks you, it puts a model of how to be a teacher, I always say that I can collect all those good things from my teachers to build me as one perfect teacher.

Likewise, having sessions in which mentors and pre-service teachers interact, work together, create strategies, and solve problems, and so forth is mandatory in their process. 
Andrea mentions in her diary how she improves since she has her teacher's guidance and her partners' feedback:

Thanks to the tips that teachers and my classmates gave me, I have improved in each class, also the conferences and the classes helped me to know about the preparation of an important class, the interest that as a teacher we should have when we are in front of many students. Also, how we can interact with them in each session and how we can prepare a good didactic class and the importance to have the lesson planned and prepared for each session.

Andrea highlights the importance of the mentor's example and guidance when they have to decide the possible paths they can follow while teaching and how they must behave with children.

Learnings from other teachers' experiences. As part of their BA program, the participants of this study have to attend lectures by experienced teachers, whose labor has somehow had a positive influence on society, education, people's lives, and so on. Those lectures are mainly focused on the experiences teachers have had, their interventions, their research, and in general the challenges they have faced along the major. As Sahan (2017) stated, "instructors whose job is to train teachers in teacher training institutions should possess themselves the teaching skills they have to teach within the scope of the pedagogical formation program" (p. 218), and it is what happened after these lectures; pre-service teachers learn from others' experiences. Alicia talks about these lectures and refers to them as a good tool to bear in mind when preparing her classes:

The workshop ... teaches me that we as teachers have to be prepared for everything. We have to have passion and preparation because we cannot go to teach something that we do not know.

As Alicia, Luis also thinks in a similar way:

The tips that a teacher gave us ... were very useful and interesting to implement in my class.

The warm-up activities make my students interested in the class and the new things that they are learning.

The previous quotes portray the importance of having mentoring, not as a one-way process, but as a multiple-way process in which pre-service teachers are able to feel they can express themselves and their peers and mentor are going to listen; this could be a more enriching experience for both the mentor and pre-service teacher, and could contribute to the improvement of the pedagogical experience.

\section{Pre-service English Language Teachers' Language Teaching}

The teaching practicum offered participants a valuable opportunity to examine in which fields they needed improvement, and it also revealed their positions and visions in regard to 
teaching. These visons allow us to analyze how aware pre-service teachers are of the way they teach and what they need to improve their practice. In this regard, we have identified two main aspects: the first one has to do with what pre-service students' reflections tell us about their vision of teaching, and the second one shows how teaching helps them to learn about pedagogical aspects.

Objectification and normalization of ELT through the reflection process. One source of reflection for participants is the recognition of what went well or bad during the development of a class. What some pre-service students commented shows that there is a lack of "in action" reflection (Schön as cited in Cote, 2012) which has to do with those decisions made as soon as some situations emerged in the classroom, as it is stated here by Laura:

My experience also helps me to notice some mistakes that I usually made as: not having prepared funny and creative activities or strategies to control my class... also to scream and lost the control of myself and my students; which is depressing.

As is evident, the pre-service teacher recognizes that during her teaching practicum she struggles to solve some problems that arise in the classroom; this is part of the objectification of the language teaching (Reagan, 2004).

This objectification of language teaching is also seen in the way pre-service students assume the concept of strategy:

It was an incredible experience that prepares us for the real context and gives us strategies and tools to our future... but now, what kind of strategies I am going to use? I need to use a didactic to teach, like using some types of games and strategies to catch the attention of the girls. (Laura)

I have to look for different methodologies to teach because when I used the same methodology I realized that the girls get bored, so I have to look for different activities. (Luis)

The instrumentalization of the concepts "strategy" and "methodology", the assumption that there is a strategy and a methodology outside, ready to be found and to be used, that suits perfectly the context they are dealing with, produces the effect that pre-service teachers see language teaching as a technical profession in which the tools and devices are already designed and what they have to do is only find the correct one and implement it without any analysis (Crandall, 2000; Kumaravadivelu, 2003).

Continuing in the same vein, the objectification of language has also to do with the vision that language is a set of structures that must be carefully saved in our memories, and pre-service teachers have not detached from that idea, as is evident in this quote:

In order to avoid the traditional method, where the main purpose is to write a lot and memorize many words, I try to reinforce students' pronunciation and the construction of sentences. (Alicia) 
Alicia has learned that language is composed of a series of rules that children have to learn by heart, but she has forgotten that language is a means to construct the world, to understand what happens around us, and even more so, that children are in the process of constructing different notions of what happens around them, and with this objectification of language we are denying them the opportunity to really understand the world.

When pre-service teachers start their pedagogical practicum, they usually connect the experience they have lived in their classes as students to the idea of what the classroom should be. It is not only reflected in the way they assume their teaching but how they see discipline, as the following quotes show:

The first three weeks were the most challenging for me, the girls got distracted easily so it was hard to control them and make them do all the activities that I have prepared. (Andrea)

For the next semester, I need to be stronger with the girls because sometimes they don't feel that I was their authority. (Laura)

The first thing I realized was the groups' lack of discipline but over the course of time they improved a lot, also because I was always a serious teacher without being aggressive... the thing I liked the most is that "my no complaining policy" worked because in the first two classes I missed about 20 minutes listening to senseless complaints. (Luis)

These three pre-service language teachers are assuming discipline to be a mechanism that must be used to control students. The idea of having a normalized classroom, with nobody talking, walking, or doing anything different than staring at the teacher who is in front of the classroom, is completely opposite to the principles of learning.

According to Magrini (2014), learning is not about transferring, retrieving, or applying knowledge; learning in an original way is to already know phenomena and to withdraw them in order to understand them. So, learning cannot happen easily in a normalized classroom, where every single student is seen as an empty vessel that has to be full of the teacher's knowledge (Freire, 1996). However, pre-service teachers had many learning opportunities along their pedagogical practicum; these learnings will be portrayed in the next section.

Teaching as an opportunity for learning. The teaching practicum is constituted as a perfect scenario for learning about different aspects. In first place, pre-service teachers' reflections show that they are in a constant process of reexamining their practices in order to understand what happened and how to solve different situations in the classroom. The following quote represents the general opinion that pre-service teachers hold about this issue:

The teacher should know how to overcome these situations in the best way, which represents a challenge for every teacher, even for an unexperienced teacher. The work is not limited to teaching or transmitting theory, it is a task that requires more time and dedication than I thought...I learned 
that the work of a teacher goes beyond teaching purely theoretical knowledge. To be a teacher, for me, it's to train a human being in all aspects. (Laura)

As can be elicited, pre-service teachers are in a constant reflection about what they do in the classroom, and also how their students respond to their classes. Laura shows that, for her, teaching English cannot be limited to teaching grammar, and she discovered that it is a task that needs time to be thought about and prepared. Additionally, she also found it important to recognize that teaching is a social activity that has a direct impact on others, in this case, little children in third grade. These realities must affect directly the way pre-service teachers see education and foster changes in methodologies for teaching English, beyond those that focus only on grammar (Kumaravadivelu, 2003; Lucero, 2016)

The previous quote and the next one show also an initial understanding of what pedagogical knowledge is:

For me as a teacher in training, the pedagogical knowledge is an articulate axis in which the teacher develops skills to interpret, understand and to know how to guide students. (Luis)

Laura and Luis are aware of the importance of relating theory and practice, and how what happens in the classroom is essential to tracing the methodological tracks they will follow in future experiences (Lucero, 2016). A pre-service teacher must be aware of the circumstances of individuals, especially because they are human beings with different backgrounds, needs, expectations, and understandings of the world. This fact demands from pre-service teachers the development of other skills that are not included in the curriculum.

Finally, we could find that pre-service teachers felt that they had improved their English language skills, as reflected in the next quote:

My English improved a lot because I have to review and prepare my classes, and this forces me to be the best for the reason that I was a teacher. (Laura)

This improvement is also justified with what Alicia mentions:

I think that teaching English represents a double challenge for the teacher. Not only do you have to worry about everything that has to do with pedagogy but also with the use of the language, or rather, the proper use of the language. (Alicia)

In this way, we can observe that teaching a language implies a process of self-recognition, not only in the methodological aspect but also in the linguistic and even the personal one.

\section{Conclusions}

Pre-service English teachers' reflections let us understand some issues related to the experience of being in the teaching practicum for the first time in the major. The results 
reveal that, for pre-service English language teachers, understanding their own classroom is one of their main concerns; however, learning from their mentors and partners allow them to reconsider the way they perceive the classroom, the strategies they use to teach, the role they play as teachers and the impact they could have on their pupils' lives.

Pre-service English teachers clamor for having more time to share their experiences to empower their own practicum as well as that of their colleagues. Not having reflection activities where they can bring out their real perceptions about their pupils, the context where they are teaching, their fears and problems in the classroom, could become a negative issue when they are facing their classes. Then, tutors are the ones who are in charge of encouraging pre-service teachers to overcome not only their real classroom issues but the academic dilemmas when they realize they are not prepared enough for language teaching.

In terms of how pre-service English teachers see language teaching, we can conclude that there is an objectification of the language that conduces to reify teaching and learning. Therefore, language and teaching are perceived by pre-service language teachers as instruments that have already been designed by someone else, and which they cannot modify or contest. As a result, teaching a language turns into a technical activity in charge of transmitting rules and controlling learning through pre-established methodologies and strategies (Kumaravadivelu, 2003; Reagan, 2004).

This fact requires that language teacher education programs revise their curriculums and allow students to have different perspectives of what language teaching means. This could contribute to having more critical students who could propose methodologies within a local perspective. This local perspective includes an aspect that some pre-service teachers mentioned in their reflections: looking at children as human beings who have the right of being heard and taken into account in the teaching process, and also to see themselves as a cognitive subject, able to read and assume contexts and able to seek opportunities for transformation through education.

From our perspective, one of the first steps to reform initial teacher education is to listen to those directly involved in the process, particularly the pre-service teachers. For that reason, we decided to collect some impression from a group of pre-service language teachers with the aim of unveiling their understanding of their own classroom, the learnings from their mentor teacher, and their mastering the art of language teaching in general.

Bearing in mind what pre-service teachers shared in their reflections, one sees that the idea of having "an ideal classroom" falls within the traditional patterns where pupils have to be sitting in front of the teacher, paying attention to every single word and movement the teacher makes and following instructions in a very careful and respectful way. Hence, breaking off with the traditional methodologies and practices would be a mandatory issue to be reconsidered in all the Bachelor programs. 
Finally, we can conclude that pre-service English teachers' experiences are an excellent source of information that needs to be considered in curriculum design, especially in regard to the designing of new spaces for teaching practicum that can provide opportunities of growing professionally and personally; so, it is imperative that language teacher education programs provide mechanisms and open spaces for allowing pre-service English teachers' voices to be heard.

\section{References}

Aguirre, I. (2014). Exploring pre-service EFL teachers' beliefs about their roles in an elementary school classroom in regard to pedagogical and emotional aspects of students. HOW, 21(1), 26-41. https://doi.org/10.19183/how.21.1.13.

Aguirre, J., \& Ramos, B. (2011). Fostering skills to enhance critical educators: A pedagogical proposal for pre-service teachers. HOW, 18(1), 169-197.

Barbour, R. (2014). Introducing qualitative research: A student's guide (2nd ed.). London, UK: Sage.

Berg, B., \& Lune, H. (2012). Qualitative research methods for the social sciences (8th ed.). Upper Saddle River, US: Pearson.

Bonilla, X. (2012). TEFL educational principles: A proposal for changing times. Colombian Applied Linguistics Journal, 14(2), 181-192. https://doi.org/10.14483/udistrital.jour.calj.2012.2.a11.

Bonilla, X., \& Méndez, P. (2008). Mentoring in pre-service teaching: From reflection on practice to a didactic proposal. Revista Actualidades Pedagógicas, 52, 79-90.

Bullough, R. V. (1990). Supervision, mentoring and self-discovery: A case study of a first-year teacher. Journal of Curriculum and Supervision, 5(4), 338-360.

Calderhead, J. (1988). Learning from introductory school experience. Journal of Education for Teaching, 14(1), 75-83. https://doi.org/10.1080/0260747880140106.

Camacho, D. Z., Becerra, L. D., Albarracin, J. C., Arciniegas, M. V., Cáceres, M., \& Cote, G. E. (2012). How can a process of reflection enhance teacher-trainees' practicum experience? HOW, 19(1), 48-60.

Cárdenas, A., \& Suárez, J. M. (2009). Pre-service teachers' knowledge base at La Salle University. HOW, 16(1), 113-130.

Cárdenas, M. L., Nieto, M. C., \& Martin, Y. M. (2005). Conditions for monograph projects by preservice teachers: Lessons from the long and winding route. Colombian Applied Linguistics Journal, 7, 75-94.

Castañeda-Peña, H., Rodríguez-Uribe, M., Salazar-Sierra, A., \& Chala-Bejarano, P. A. (2016). Narrative events of pre-service teachers at the end of their teaching practicum with regard to their pedagogical advisor: Learnings reported. Signo y Pensamiento, 35(68), 52-64. https://doi. org/10.11144/Javeriana.syp35-68.neps.

Castellanos, J. (2013). The role of English pre-service teachers' beliefs about teaching in teacher education programs. Profile: Issues in Teachers' Professional Development, 15(1), 195-206. 
Castillo, R., \& Díaz, N. (2012). Supporting student-teacher researchers' quest for their voice. HOW, 19(1), 185-193.

Castro, A. Y., \& López, S. F. (2014). Communication strategies used by pre-service English teachers of different proficiency levels. HOW, 21(1), 10-25. https://doi.org/10.19183/how.21.1.12.

Cote, G. E. (2012). The role of reflection during the first teaching experience of foreign language pre-service teachers: an exploratory-case study. Colombian Applied Linguistics Journal, 14(2), 2434. https://doi.org/10.14483/udistrital.jour.calj.2012.2.a02.

Crandall, J. (2000). Language teacher education. Annual Review of Applied Linguistics, 20, 34-55. https://doi.org/10.1017/S0267190500200032.

Fajardo, A. (2013). Stated vs. enacted beliefs: Looking at pre-service teachers' pedagogical beliefs through classroom interaction. Íkala, Revista de Lenguaje y Cultura, 18(2), 37-57.

Fajardo, J. A., \& Miranda, I. R. (2015). The paradox of the practicum: Affinity to and resistance towards teaching. Íkala, Revista de Lenguaje y Cultura, 20(3), 329-341.

Fandiño, Y. J. (2013). Knowledge base and EFL teacher education programs: A Colombian perspective. Íkala, Revista de Lenguaje y Cultura, 18(1), 83-95.

Farrell, T. S. C. (2001). English language teacher socialisation during the practicum. Prospect, 16(1), 46-62.

Ferrier-Kerr, J. L. (2009). Establishing professional relationships in practicum settings. Teaching and Teacher Education, 25(6), 790-797. https://doi.org/10.1016/j.tate.2009.01.001.

Franco, C. P., \& Galvis, H. A. (2013). The role of situational context and linguistic context when testing EFL vocabulary knowledge in a language teacher education program: A preliminary approach. Colombian Applied Linguistics Journal, 15(1), 85-99. https://doi.org/10.14483/udistrital.jour.calj.2013.1.a06.

Freeman, D. (2001). Second language teacher education. In D. Nunan \& R. Carter (Eds.), The Cambridge guide to teaching English to speakers of other languages (pp. 72-79). Cambridge, UK: Cambridge University Press. https://doi.org/10.1017/CBO9780511667206.011.

Freire, P. (1996). Pedagogía de la esperanza [Pedagogy of hope] (2nd ed.). México D.F., MX: Siglo XXI Editores.

Granados-Beltrán, C. (2016). Critical interculturality: A path for pre-service ELT teachers. Íkala, Revista de Lenguaje y Cultura, 21(2), 171-187.

Gutiérrez, C. P. (2015). Beliefs, attitudes, and reflections of EFL pre-service teachers while exploring critical literacy theories to prepare and implement critical lessons. Colombian Applied Linguistics Journal, 17(2), 179-192. https://doi.org/10.14483/udistrital.jour.calj.2015.2.a01.

Higuita, M., \& Díaz, A. (2015). Docentes noveles de inglés en shock: ¿qué factores lo generan? [Novice English teachers in shock: Which factors are behind it?]. Íkala, Revista de Lenguaje y Cultura, 20(2), 173-185.

Kagan, D. M. (1992). Professional growth among preservice and beginning teachers. Review of Educational Research, 62(2), 129-169. https://doi.org/10.3102/00346543062002129. 
Korthagen, F. A., \& Vasalos, A. (2005). Levels in reflection: Core reflection as a means to enhance professional growth. Teachers and Teaching: Theory and Practice, 11(1), 47-71. https://doi.org/10 .1080/1354060042000337093.

Kumaravadivelu, B. (2003). Beyond methods: Macrostrategies for language teaching. New Haven, US: Yale University Press.

Lucero, E. (2016). Reflections upon a pedagogical practice experience: Standpoints, definitions, and knowledge. In R. M. Páez (Ed.), Práctica y experiencia: claves del saber pedagógico docente (pp. 143-168). Bogotá, CO: Ediciones Unisalle.

Macías, D. F., \& Sánchez, J. A. (2015). Classroom management: A persistent challenge for pre-service foreign language teachers. Profile: Issues in Teachers' Professional Development, 17(2), 81-99. https://doi.org/10.15446/profile.v17n2.43641.

Magrini, J. (2014). Social efficiency and instrumentalism in education: Critical essays in ontology, phenomenology, and philosophical hermeneutics. New York, US: Routledge.

Martínez Boom, A. (2009). La educación en América Latina: un horizonte complejo [Education in Latin America: A complex horizon]. Revista Iberoamericana de Educación, (49), 163-179.

Méndez, P. E., \& Bonilla, X. (2016). Diseño, implementación y evaluación de prácticas pedagógicas en un programa de licenciatura con énfasis en inglés [Design, implementation and evaluation of teaching practices in a bachelor program with emphasis on English]. Colombian Applied Linguistics Journal, 18(2), 49-66. https://doi.org/10.14483/calj.v18n2.8197.

Morales, Y. A. (2016). Unveiling pre-service teachers' attitudes toward teaching: The role of pedagogical practicums. Profile: Issues in Teachers' Professional Development, 18(2), 47-61. https:/ / doi. org/10.15446/profile.v18n2.49591.

Orland-Barack, L., \& Yinon, H. (2007). When theory meets practice: What student teachers learn from guided reflection on their own classroom discourse. Teaching and Teacher Education, 23(6), 957-969. https://doi.org/10.1016/j.tate.2006.06.005.

Patrick, H., \& Ryan, A. M. (2005). Identifying adaptive classrooms: Dimensions of the classroom social environment. In K. A. Moore \& L. H. Lippman (Eds.), What do children need to flourish? Conceptualizing and measuring indicators of positive development (pp. 271-287). New York, US: Springer. https://doi.org/10.1007/0-387-23823-9_17.

Peters, J. H. (2012). Are they ready? Final year pre-service teachers' learning about managing student behaviour. The Australian Journal of Teacher Education, 37(9), 18-42. https://doi. org/10.14221/ajte.2012v37n9.2.

Posada, J. Z., \& Garzón, E. (2014). Bridging the gap between theory and practice in a B.A. program in EFL. HOW, 21(1), 122-137. https://doi.org/10.19183/how.21.1.19.

Ramos, B. (2013). Towards the development of intercultural competence skills: A pedagogical experience with pre-service teachers. HOW, 20(1), 206-225.

Reagan, T. (2004). Objectification, positivism and language studies: A reconsideration. Critical Inquiry in Language Studies, 1(1), 41-60. https://doi.org/10.1207/s15427595cils0101_3. 
Richards, K. (2003). Qualitative inquiry in TESOL. New York, US: Palgrave McMillan. https://doi. org/10.1057/9780230505056.

Sahan, H. (2017). Pre-service teachers' perceptions of instructors' teaching skills. Journal of Education and Learning, 6(3), 217-228. https://doi.org/10.5539/jel.v6n3p217.

Samacá, Y. (2012). On rethinking our classrooms: A critical pedagogy view. HOW, 19(1), 194-208.

Trent, J. (2013). From learner to teacher: Practice, language, and identity in a teaching practicum. Asia-Pacific Journal of Teacher Education, 41(4), 426-440. https://doi.org/10.1080/13598 66X.2013.838621.

Viáfara, J. J. (2008). From pre-school to university: Student-teachers characterize their EFL writing development. Colombian Applied Linguistics Journal, 10, 73-92.

Viáfara, J. J. (2016). "I'm missing something": (Non)nativeness in prospective teachers as Spanish and English speakers. Colombian Applied Linguistics Journal, 18(2), 11-24. https://doi. org/10.14483/calj.v18n2.9477.

\section{The Authors}

Jairo Enrique Castañeda-Trujillo is an assistant teacher and researcher in the BA program in modern languages and Spanish, Universidad de La Salle (Colombia). He is currently pursuing a $\mathrm{PhD}$ degree in education with an emphasis on English language teaching at Universidad Distrital Francisco José de Caldas (Colombia).

Ana Jackelin Aguirre-Hernández is an English language teacher and researcher in the BA program in modern languages and Spanish, Universidad de La Salle (Colombia). She holds an M.Ed. from Universidad de los Andes (Colombia) and a BA in English teaching from Universidad Distrital Francisco José de Caldas (Colombia). 